\title{
Latent HIV-1 Can Be Reactivated by Cellular Superinfection in a Tat- Dependent Manner, Which Can Lead to the Emergence of Multidrug- Resistant Recombinant Viruses
}

\author{
Daniel A. Donahue, ${ }^{a, b}$ Sophie M. Bastarache, ${ }^{a, b}$ Richard D. Sloan, ${ }^{a, b *}$ Mark A. Wainberg ${ }^{a, b}$ \\ McGill University AIDS Centre, Lady Davis Institute, Jewish General Hospital, Montreal, Québec, Canadaa; Department of Microbiology and Immunology, McGill University, \\ Montreal, Québec, Canadab
}

The HIV-1 latent reservoir represents an important source of genetic diversity that could contribute to viral evolution and multidrug resistance following latent virus reactivation. This could occur by superinfection of a latently infected cell. We asked whether latent viruses might be reactivated when their host cells are superinfected, and if so, whether they could contribute to the generation of recombinant viruses. Using populations of latently infected Jurkat cells, we found that latent viruses were efficiently reactivated upon superinfection. Pathways leading to latent virus reactivation via superinfection might include gp120CD4/CXCR4-induced signaling, modulation of the cellular environment by Nef, and/or the activity of Tat produced upon superinfection. Using a range of antiviral compounds and genetic approaches, we show that gp120 and Nef are not required for latent virus reactivation by superinfection, but this process depends on production of functional Tat by the superinfecting virus. In a primary cell model of latency in unstimulated CD4 T cells, superinfection also led to latent virus reactivation. Drug-resistant latent viruses were also reactivated following superinfection in Jurkat cells and were able to undergo recombination with the superinfecting virus. Under drug-selective pressure, this generated multidrug-resistant recombinants that were identified by unique restriction digestion band patterns and by population-level sequencing. During conditions of poor drug adherence, treatment interruption or treatment failure, or in drug-impermeable sanctuary sites, reactivation of latent viruses by superinfection or other means could provide for the emergence or spread of replicatively fit viruses in the face of strong selective pressures.

atently infected resting CD4 T cells represent the major barrier to curing HIV-1 infection. In all HIV-1-infected individuals, a latent reservoir is established very early after acute infection $(1,2)$. Latent viruses are replication-competent proviruses that are integrated into cellular chromosomal DNA and do not produce viral particles but can lead to virus production following appropriate activation signals. Multiple mechanisms are involved in both the establishment and maintenance of latency, and these generally act to suppress viral transcription or to limit gene expression from any viral transcripts produced (recent reviews include references $3,4,5,6$, and 7). Since latent viruses are nonreplicating, they are not affected by host immune responses or by antiretroviral therapy. Reactivation and depletion of the latent reservoir are currently a major goal of the field, and multiple clinical trials have been carried out or are under way $(8,9)$. Nonetheless, eradication of latent reservoirs is far from being achieved at present.

Treatment failure can occur when viruses develop resistance to one or more of the drugs in a treatment regimen. Since viruses can be continually deposited into the latent reservoir during periods of low-level viremia or during treatment failure and can exit the latent reservoir when their host cell is activated (10), latency provides a means for the archiving and reemergence of sequences representing the history of a patient's quasispecies. When drugresistant viruses are present, they are also archived in the latent reservoir (11-15). Since viral rebound from latently infected cells occurs upon treatment interruption or treatment failure (16), previously existing drug-resistant viruses that are present in the latent reservoir preclude patients from being treated with that drug or drug combination in the future.

Cells multiply infected with HIV-1 in vivo have been previously reported. This is especially common in secondary lymphoid tis- sues (17), where the majority of lymphocytes reside, and splenocytes have been reported to harbor 3 to 4 proviruses on average, with some cells containing up to 8 proviruses (18). In addition, 5 to $25 \%$ of infected lymphocytes in peripheral blood were reported to carry multiple proviruses (19). Multiply infected cells can arise from one of two general mechanisms, namely, by simultaneous infection by several viruses or by sequential infection. Cell-to-cell transmission has been shown to lead to the simultaneous transfer of multiple virions across virological synapses in a process referred to as multiploid inheritance (20), leading to multiple integrated, transcriptionally active proviruses (21). In addition, the formation of polysynapses can lead to simultaneous transmission of virions from one infected cell to multiple target cells (22). By locally increasing the multiplicity of infection, polysynapses might contribute to the generation of multiply infected cells by both cell-to-cell transmission as well as by superinfection. Superinfection, whether by cell-to-cell transmission or cell-free infection, leads to the generation of multiply infected cells via sequential infection (23).

The extreme genetic diversity of HIV-1 is a result of the high

Received 30 April 2013 Accepted 17 June 2013

Published ahead of print 26 June 2013

Address correspondence to Mark A. Wainberg, mark.wainberg@mcgill.ca.

* Present address: Richard D. Sloan, Centre for Immunology and Infectious Disease, Blizard Institute, Barts, and the London School of Medicine and Dentistry,

Queen Mary, University of London, London, United Kingdom.

Copyright @ 2013, American Society for Microbiology. All Rights Reserved. doi:10.1128/JVI.01165-13 
rate of nucleotide misincorporation and the propensity for template switching by the viral reverse transcriptase (RT). Retroviruses package two genomic RNA molecules into each viral particle, and RT switches between these two templates several times during the process of reverse transcription (reviewed in references 24 and 25). During infection of Jurkat T cells, an average of 7 to 8 template switches per virus were reported to occur at essentially random locations, and an average of 30 template switches per virus were reported in macrophages (26). Multiply infected cells can produce heterozygous virions, which can result in the formation of recombinant viruses when RT switches between nonidentical templates during reverse transcription. The large number $(>50)$ and high prevalence of circulating recombinant forms (CRFs) demonstrate the evolutionary success of HIV-1 recombinants on a global scale (27). Recombination within individual patients has been documented in numerous studies (reviewed in reference 25), and recombination involving drug-resistant viruses provides a mechanism for the spread of drug resistance throughout a patient's quasispecies (28-30).

Since the latent reservoir represents an archive of the history of a patient's quasispecies, including viruses with any previously existing drug resistance mutations (11-15), latent viruses represent an important source for the further generation of genetic diversity under selective pressure. This could occur following superinfection of a latently infected cell. Superinfection of latently infected cells could occur either during treatment interruption or failure, during periods of low-level viremia, or in compartmentalized sites of viral replication such as sanctuary sites that might result from poor drug penetration. Although this process is likely to be rare, the combination of the high multiplicity of infection that is common in vivo coupled with the potentially strong selective advantage of any resulting recombinant viruses renders this an important process $(31,32)$. In fact, it has been suggested that superinfection might modulate levels of latency for many viruses, including HIV (33), and it has been suggested that latent viruses might contribute to $\mathrm{HIV}-1$ recombination in vivo $(25,34)$.

In this study, we asked whether latent viruses would be reactivated upon superinfection of their host cells, and if so, whether they could contribute to the generation of recombinant viruses. Using cell line and primary cell models of HIV-1 latency, we found that superinfection reactivated latent viruses and that this process required Tat production from the superinfecting virus. We also found that reactivated, drug-resistant latent viruses could contribute to the development of multidrug resistance via recombination with superinfecting viruses.

\section{MATERIALS AND METHODS}

Cell lines, viruses, and antiviral compounds. Jurkat (clone E6-1) and HeLa-tat-III (HeLa-tat) cells were obtained through the NIH AIDS Research and Reference Reagent Program. Jurkat cells were maintained in RPMI 1640 medium (Invitrogen) supplemented with 10\% fetal bovine serum (FBS), 1\% L-glutamine, and $1 \%$ penicillin-streptomycin. HeLa-tat and 293T cells were maintained in Dulbecco's modified Eagle's medium (DMEM) (Invitrogen) supplemented with $10 \%$ FBS, $1 \%$ L-glutamine, and $1 \%$ penicillin-streptomycin. pNL4-3- $\Delta$ E-EGFP (expressing enhanced green fluorescent protein) was obtained through the NIH AIDS Research and Reference Reagent Program, while pBR-NL4-3-IRES-EGFP (containing an internal ribosome entry site), pBR-NL4-3-IRES-dsRed, and pBR-NL4-3-IRES-dsRed-nef-stop were kind gifts from J. Münch and F. Kirchhoff (35). The following constructs were created by either site-directed mutagenesis or cloning: pNL4-3- $\Delta$ E-EGFP-
tat(H13L), pNL4-3- $\Delta$ E-EGFP-tat(H13L)-RT( $\Delta$ Sbfl/K103N), pBR-NL4-3IRES-dsRed-RT(M184V/AMboI), pBR-NL4-3-IRES-dsRed-tat(H13L), and pBR-NL4-3-IRES-dsRed-tat(C22G). The nucleotide changes introduced are as follows: tat H13L, CAT to TTA; tat C22G, TGT to GGA; $\triangle$ Sbfl, CCTG CAGG to CCTGCTGG; RT K103N, AAA to AAC; RT M184V, ATG to GTG; $\triangle \mathrm{MboI}$, GATC to GTTC. Replication-competent reporter viruses were produced by transfection of $\sim 9 \times 10^{6} 293 \mathrm{~T}$ cells with $25 \mu \mathrm{g}$ of plasmid DNA using Lipofectamine 2000 (Invitrogen). The viruses used in Fig. 3 [pBR-NL4-3-IRES-dsRed-tat(wt/H13L/C22G), where "wt" represents "wild type"] were produced under the same conditions, except by transfection of HeLa-tat cells. Pseudoviruses were produced by cotransfection of $293 \mathrm{~T}$ cells with $6.25 \mu \mathrm{g}$ pVPack-VSV-G (Stratagene)-a vesicular stomatitis virus $G$ protein (VSV-G) envelope-encoding construct-in combination with $18.75 \mu \mathrm{g}$ of pNL4-3- $\Delta \mathrm{E}$-EGFP derivatives, as described above. All transfections were carried out using Opti-MEM medium (Invitrogen) supplemented with $2.5 \%$ FBS. Virus-containing supernatants were harvested at $48 \mathrm{~h}$ posttransfection, clarified by centrifugation for $5 \mathrm{~min}$ at $470 \times g$, and passed through a $0.45-\mu \mathrm{m}$-pore filter. All viruses were then treated with $50 \mathrm{U} / \mathrm{ml}$ benzonase (Sigma) in the presence of added benzonase buffer $(10 \times=500 \mathrm{mM}$ Tris- $\mathrm{HCl}[\mathrm{pH} 8.0], 10 \mathrm{mM}$ $\mathrm{MgCl}_{2}$, and $1 \mathrm{mg} / \mathrm{ml}$ bovine serum albumin [BSA] ) at $37^{\circ} \mathrm{C}$ for $20 \mathrm{~min}$ to digest residual plasmid DNA. Viral titers were determined by enzymelinked immunosorbent assay (ELISA) for viral capsid (p24), using a Vironostika HIV-1 antigen (Ag) kit (bioMérieux). The RT inhibitor efavirenz $(\mathrm{EFV})$, the integrase inhibitor raltegravir (RAL), and the protease (PR) inhibitor darunavir (DRV) were obtained through the NIH AIDS Research and Reference Reagent Program.

Jurkat cell latency model. Populations of latently infected cells were established as described previously (36). Briefly, Jurkat cells were infected with VSV-G-pseudotyped NL4-3- $\Delta$ E-EGFP-tat(H13L) or NL4-3- $\Delta \mathrm{E}$ EGFP-tat(H13L)-RT( $\Delta$ SbfI/K103N) and were cultured for up to 2 months. At various time points, samples were treated for $24 \mathrm{~h}$ with tumor necrosis factor $\alpha$ (TNF- $\alpha)(20 \mathrm{ng} / \mathrm{ml})$ to reactivate latent viruses, before being fixed in $2 \%$ paraformaldehyde for $20 \mathrm{~min}$. Flow cytometry was performed using a FACSCalibur or LSRFortessa cell analyzer (Becton, Dickinson), and data were analyzed with either FCS Express or FlowJo software. Live cells were gated by forward and side scatter properties, single cells were then gated based on forward and side scatter width and height, and levels of EGFP were then measured.

Primary cell latency model. A previously described primary cell latency model (37) was used with minor modifications. Peripheral blood mononuclear cells (PBMC) were isolated from blood of HIV-1-negative donors by Ficoll-Hypaque density gradient centrifugation and were immediately processed to isolate unstimulated CD4 T cells using a Dynabeads untouched human CD4 T-cell isolation kit (Invitrogen). Isolated cells were stained with anti-CD3-phycoerythrin (PE), anti-CD4-e450, and anti-CD69-fluorescein isothiocyanate (FITC) and acquired on an LSRFortessa cell analyzer. Isolated CD4 T cells were cultured overnight in RPMI supplemented with $10 \%$ FBS, $1 \%$ L-glutamine, and $1 \%$ penicillinstreptomycin, in the absence of interleukin-2 (IL-2). The following day, CD4 T cells $(\sim 0.5$ million) were infected with NL4-3-IRES-dsRed (wt or H13L tat) by spinoculation in 5-ml polystyrene tubes at $1,200 \times g$ for $2 \mathrm{~h}$ at $25^{\circ} \mathrm{C}$, using $200 \mathrm{ng} \mathrm{p} 24$ per million cells (50\% virus-containing supernatant and 50\% supplemented RPMI, by volume). Immediately after spinoculation, cells were resuspended in supplemented RPMI in the presence of $1 \mu \mathrm{M}$ DRV and then cultured in 96-well round-bottom plates for 3 days. On day 3 postinfection (p.i.), samples of uninfected or infected cells were incubated with anti-CD3/CD28 magnetic beads (Invitrogen), using 1 bead per cell in the presence of $10 \mu \mathrm{M}$ RAL, to reactivate postintegration latent viruses. Cells were fixed 48 or $72 \mathrm{~h}$ later and used for flow cytometry.

Superinfection. (i) Jurkat cells. A total of $2 \times 10^{5}$ Jurkat cells latently infected with NL4-3- $\Delta$ E-EGFP-tat(H13L), or uninfected Jurkat cells were infected with NL4-3-IRES-dsRed (or its tat/nef mutant derivatives: $120 \mathrm{ng}$ p24 was used for each virus in Fig. 1 and 2, while $90 \mathrm{ng}$ p24 was used for the 
viruses in Fig. 3. A wide range of superinfecting virus levels were used, as indicated, in Fig. 4. Similarly, $2 \times 10^{5}$ Jurkat cells latently infected with NL4-3- $\Delta$ E-EGFP-tat (H13L)-RT( $\Delta$ Sbfl/K103N) or uninfected Jurkat cells were infected with $300 \mathrm{ng}$ p24 of NL4-3-IRES-dsRed-RT(M184V/ $\Delta \mathrm{MboI})$. Infections were by spinoculation at $1,500 \times g$ for $2 \mathrm{~h}$ at $37^{\circ} \mathrm{C}$ in the presence of EFV, RAL, or DRV as required ( $1 \mu \mathrm{M}$ each). Following spinoculation, cells were allowed to rest for $1 \mathrm{~h}$ at $37^{\circ} \mathrm{C}$ and then were resuspended in supplemented RPMI containing EFV, RAL, or DRV as required. At $72 \mathrm{~h}$ p.i., cells were fixed and analyzed by flow cytometry.

(ii) Primary cells. Latently infected CD4 T cells (3 days p.i.) were superinfected by spinoculation with NL4-3-IRES-GFP (or supplemented RPMI for controls; $1,200 \times g$ for $2 \mathrm{~h}$ at $25^{\circ} \mathrm{C}$ ), using $200 \mathrm{ng}$ p 24 per million cells. Cells were cultured in supplemented RPMI (in the absence of IL-2) plus $1 \mu \mathrm{M}$ DRV for 3 days before fixation and flow cytometry.

PCR. Integrated HIV-1 DNA. A total of $2 \times 10^{5}$ Jurkat cells were infected with $90 \mathrm{ng}$ p24 of NL4-3-IRES-dsRed (or its tat mutant derivatives) by spinoculation as described above, and $1 \mu \mathrm{M}$ DRV was added to prevent reinfection. Cellular DNA was extracted 48 h p.i. using a DNeasy blood and tissue kit (Qiagen). A previously described nested Alu-gag PCR (38) was used with the following modifications. The first-round reaction (performed in both the presence and the absence of an Alu-specific primer) was performed using undiluted samples (65 ng DNA) and 1:4 dilutions of each sample (16.25 ng DNA from infected Jurkat cells diluted with DNA from uninfected Jurkat cells [65 ng DNA total]) in the presence of $2 \mathrm{mM} \mathrm{MgCl}_{2}$ and $200 \mu \mathrm{M}$ deoxynucleoside triphosphates (dNTPs) in a total volume of $20 \mu \mathrm{l}$, using the primers Alu-F (5'-GCCTCCCAAAGTG CTGGGATTACAG-3') and gag-R (5'-GTTCCTGCTATGTCACTTCC$3^{\prime}$ ). The cycling conditions were $95^{\circ} \mathrm{C}$ for $2 \mathrm{~min}$, followed by 20 cycles of $95^{\circ} \mathrm{C}$ for $15 \mathrm{~s}, 50^{\circ} \mathrm{C}$ for $15 \mathrm{~s}$, and $72^{\circ} \mathrm{C}$ for $3.5 \mathrm{~min}$. Nine microliters of the resulting first-round product was used as the template for the secondround nested reaction in the presence of $5 \mathrm{mM} \mathrm{MgCl}_{2}$ (final concentration, including carryover from the first round) and $200 \mu \mathrm{M}$ added dNTPs, in a total volume of $20 \mu \mathrm{l}$. The second-round primers were LTR-F (long terminal repeat forward) (5'-TTAAGCCTCAATAAAGCTTGCC-3') and LTR-R (long terminal repeat reverse) (5'-GTTCGGGCGCCACTGCTAG A-3'), and only the "wild-type" probe (38) was used. The second-round cycling conditions were $50^{\circ} \mathrm{C}$ for $2 \mathrm{~min}, 95^{\circ} \mathrm{C}$ for $1 \mathrm{~min}$, and 45 cycles of $95^{\circ} \mathrm{C}$ for $15 \mathrm{~s}$ and $60^{\circ} \mathrm{C}$ for $30 \mathrm{~s}$, using Platinum quantitative PCR (qPCR) SuperMix-UDG (Invitrogen) on a Corbett Rotor-Gene 6000 thermocycler. To generate a standard curve for relative quantification of integrated DNA, Alu-gag PCR was first performed on a 2-fold dilution series of DNA from infected Jurkat cells (diluted with DNA from uninfected Jurkat cells). Samples were normalized to their $\beta$-globin contents as described previously (39).

RT-PCR for viral genomic RNA. Viral RNA was extracted from supernatants of infected cells using a QIAamp viral RNA minikit (Qiagen). RT-PCR was performed using a SuperScript III one-step RT-PCR kit (Invitrogen) and $6 \mu$ l viral RNA template, with primers Recomb-F (5' -AAT GGATGGCCCAAAAGTTAAACA-3' [corresponding to HXB2 coordinates 2140 to 2163] and Recomb-R 5'-CTGTTAATTGTTTCACATCAT TAGTGTGGG-3' [corresponding to HXB2 coordinates 3174 to 3203]) in a total volume of $30 \mu \mathrm{l}$. The cycling conditions were $55^{\circ} \mathrm{C}$ for $15 \mathrm{~min}, 94^{\circ} \mathrm{C}$ for $2 \mathrm{~min}$, and $40 \mathrm{cycles}$ of $94^{\circ} \mathrm{C}$ for $20 \mathrm{~s}, 60^{\circ} \mathrm{C}$ for $20 \mathrm{~s}$, and $68^{\circ} \mathrm{C}$ for $1 \mathrm{~min}$. Products were visualized on $1 \%$ agarose Tris-acetate-EDTA (TAE) gels.

Identification of recombinant viruses. To analyze recombination by restriction digestion, $5 \mu$ l of each RT-PCR product (containing amplified viral genomic RNA) was double digested with both SbfI and MboI (New England BioLabs) in a total volume of $15 \mu \mathrm{l}$ for $15 \mathrm{~min}$ at $37^{\circ} \mathrm{C}$. Products were then visualized on $1 \%$ agarose TAE gels ( $1 \mathrm{~h}$ at $125 \mathrm{~V}$ ), and band patterns were compared to digests of plasmids representing wt, latent, or superinfecting viruses. To analyze recombination by sequencing, RT-PCR products containing amplified viral genomic RNA were sequenced by standard methods using the primers Recomb-F and Recomb-R (see above). All chromatograms were visually inspected, and chromatogram peak intensities at relevant nucleotide positions were used to calculate the relative proportion of each virus in the population. Results from forward and reverse sequence reads were averaged for each position. As described in further detail in the Results section, estimates for the percentage of recombinant viruses in each population are conservative.

Statistical analyses. Unpaired two-tailed $t$ tests, one-way analysis of variance (ANOVA), and linear regression analysis were performed with GraphPad Prism 5.0.

\section{RESULTS}

Superinfection of latently infected cells reactivates latent HIV-1. To determine whether superinfection of latently infected cells would reactivate latent viruses, we first used a Jurkat-based model of HIV-1 latency establishment and reactivation that we have previously described (36). This model takes advantage of viruses encoding the tat $\mathrm{H} 13 \mathrm{~L}$ variant that attenuates Tat activity by decreasing its interaction with P-TEFb. When H13L Tat is present at sufficient levels, it appears to be fully functional, supporting viral gene expression at levels comparable to those of wild-type tat viruses (40). However, lower concentrations of H13L Tat lead to more rapid shutdown of viral transcription compared to wt (40). This facilitates the entry into latency, since a low Tat threshold is reached sooner, allowing the establishment of latency (41-43). H13L tat viruses have been extensively characterized in the context of HIV-1 latency in both Jurkat and primary cells and represent genuinely latent viruses that behave similarly to latent viruses that encode wt Tat $(36,40,44-47)$. The use of H13L tat thus represents an experimentally useful tool to increase the number and frequency of latently infected cells available for study.

In our Jurkat latency model, a population of latent GFP reporter viruses representing diverse integration sites is established. Culturing these cells for several weeks gives rise to a heterogeneous population of cells harboring latent proviruses, with no virusproducing cells present. In the latent populations used here, $\sim 14 \%$ of cells harbored TNF- $\alpha$-inducible latent viruses (Fig. 1A and B). Uninfected Jurkat cells or latently infected Jurkat cells that encode viral EGFP were then infected with the replication-competent reporter virus NL4-3-dsRed (where dsRed is expressed from an internal ribosome entry site [IRES] from nef transcripts [35]). Superinfection of latently infected cells, in the absence of any antiviral inhibitors, led to reactivation of latent virus, as demonstrated by the increased percentage of EGFP-positive cells following superinfection (Fig. $1 \mathrm{C}$ and D).

Interaction of gp120 with CD4 and CXCR4 is not required for latent virus reactivation. We next wished to characterize the mechanism(s) by which superinfection can reactivate latent viruses. In resting or suboptimally activated CD4 T cells, interaction of gp120 with CD4 and either CCR5 or CXCR4 can lead to induction of $\mathrm{Ca}^{2+}$ and NFAT (nuclear factor of activated T cells) - an important transcription factor involved in HIV-1 transcription-in the absence of full cellular activation (48-52). Additionally, HIV-1 envelope was reported to induce viral replication from resting cells of HIV-1-infected patients (53). Latently infected cells were superinfected in the presence of inhibitory levels $(1 \mu \mathrm{M})$ of the RT inhibitor efavirenz (EFV). Blocking productive superinfection at reverse transcription, which is downstream of the gp120CD4/CXCR4 interaction, resulted in no increase in latent virus gene expression compared to that of latently infected cells that were not superinfected $(P=0.75)$ (Fig. $1 \mathrm{C}$ and $\mathrm{D})$.

Reactivation of latent viruses by superinfection requires gene expression of the superinfecting virus. Next, latently in- 

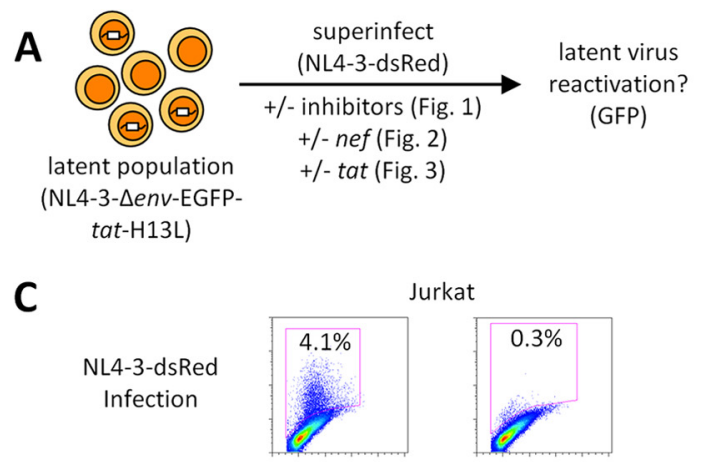

latent population

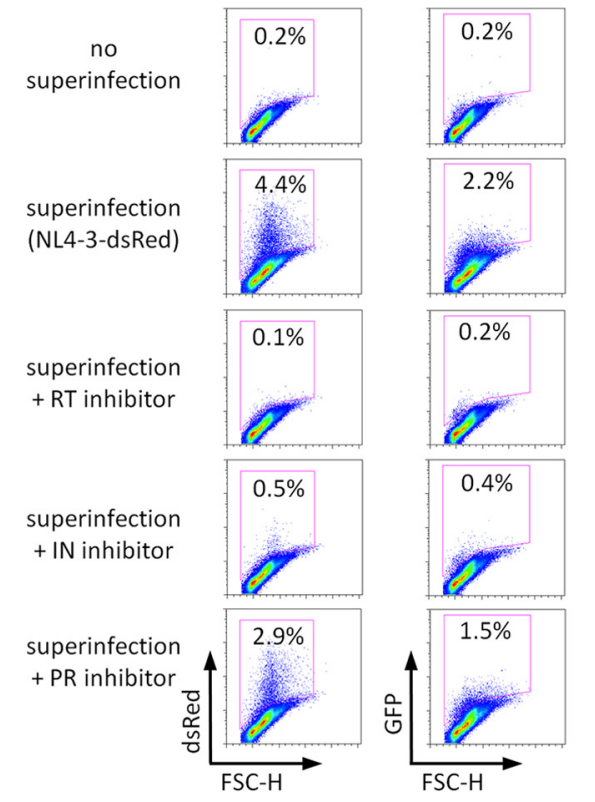

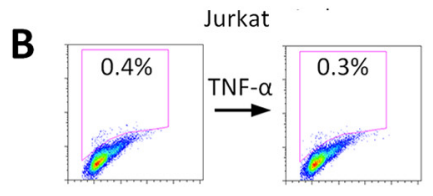

latent population
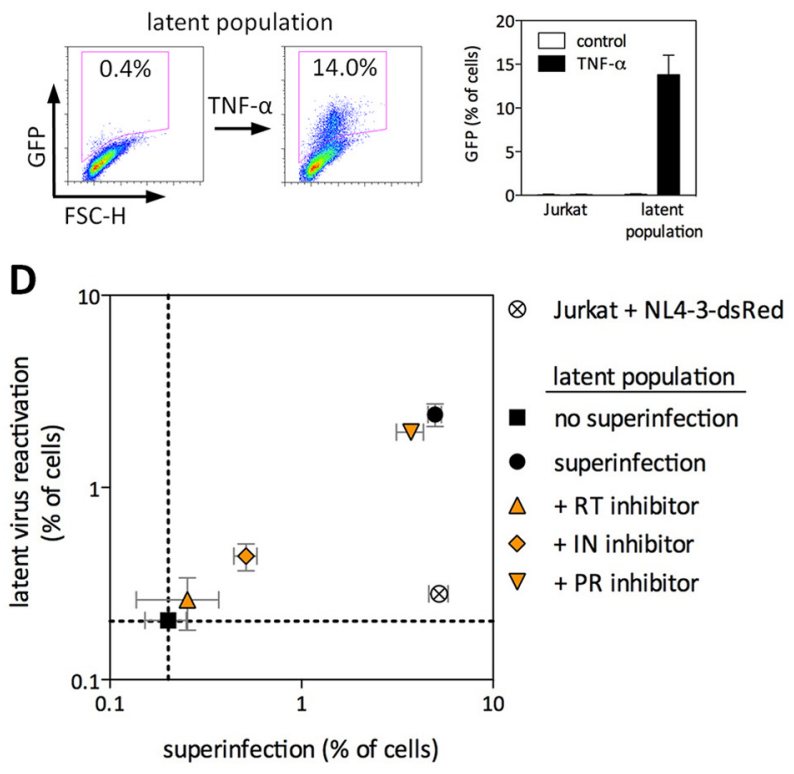

FIG 1 Superinfection of latently infected cells reactivates latent HIV-1 and requires gene expression but not gp120-CD4/CXCR4 signaling from the superinfecting virus. (A) Schematic representation of the experimental design. (B) Characterization of the latently infected Jurkat cell populations used in Fig. 1 to 4. FSC-H, forward scatter height. Results of three independent experiments performed in duplicate are shown. (C and D) Uninfected or latently infected Jurkat cells were superinfected with NL4-3-dsRed in the presence or absence of $1 \mu \mathrm{M}$ RT inhibitor EFV, IN inhibitor RAL, or PR inhibitor DRV. Representative results are shown in panel C, and the results of three independent experiments performed in triplicate are shown in panel D. dsRed represents superinfecting virus, and GFP represents latent virus. Error bars represent standard errors of the mean (SEM $[n=3$ for error bar calculations $]$ ).

fected cells were superinfected in the presence of the integrase (IN) inhibitor raltegravir (RAL), which prevents integration and thus productive viral gene expression, or in the presence of the protease (PR) inhibitor darunavir (DRV), which acts after integration and viral gene expression. As shown in Fig. $1 \mathrm{C}$ to $\mathrm{D}$, latent virus reactivation required gene expression of the superinfecting virus. It is noteworthy that superinfection in the presence of an integrase inhibitor led to a minor and borderline significant $(P=$ $0.05)$ increase in latent virus reactivation. This could be due to incomplete inhibition of viral replication in the presence of $1 \mu \mathrm{M}$ RAL, which might be explained by the comparatively poor inhibitory capacity of this drug during a single round of viral replication (54). Alternatively, low-level gene expression from unintegrated viral DNA might explain this observation (55).

Nef is not required for latent virus reactivation via superinfection. HIV-1 Nef modulates numerous cellular pathways, including several related to T-cell activation. Recent studies suggest that Nef lowers the activation threshold for CD4 T cells.
This implies that when cells encounter activation signals in the presence of Nef, greater induction of transcription factors, including NF- $\mathrm{B}$ and NFAT, as well as greater $\mathrm{Ca}^{2+}$ release and IL-2 production, can result (reviewed in references 56 and 57). Furthermore, it has been reported that Nef alone is sufficient to upregulate numerous cellular genes involved in LTR-driven transcription, including NFAT and many other transcription factors, as well as CDK9 and other factors involved in the elongation of viral transcripts (58). Expression of Nef from unintegrated DNA can also modulate T-cell activation pathways (59). We therefore wished to determine whether Nef might be contributing to the reactivation of latent viruses that we observed in Fig. 1. Latently infected cells were superinfected with a replication-competent reporter virus containing two stop codons near the start of nef ( $\Delta$ nef virus). Consistent with the enhancement of infectivity associated with Nef, superinfection with $\Delta$ nef virus resulted in fewer dsRed-positive cells compared to superinfection with Nef-encoding virus. However, latent vi- 

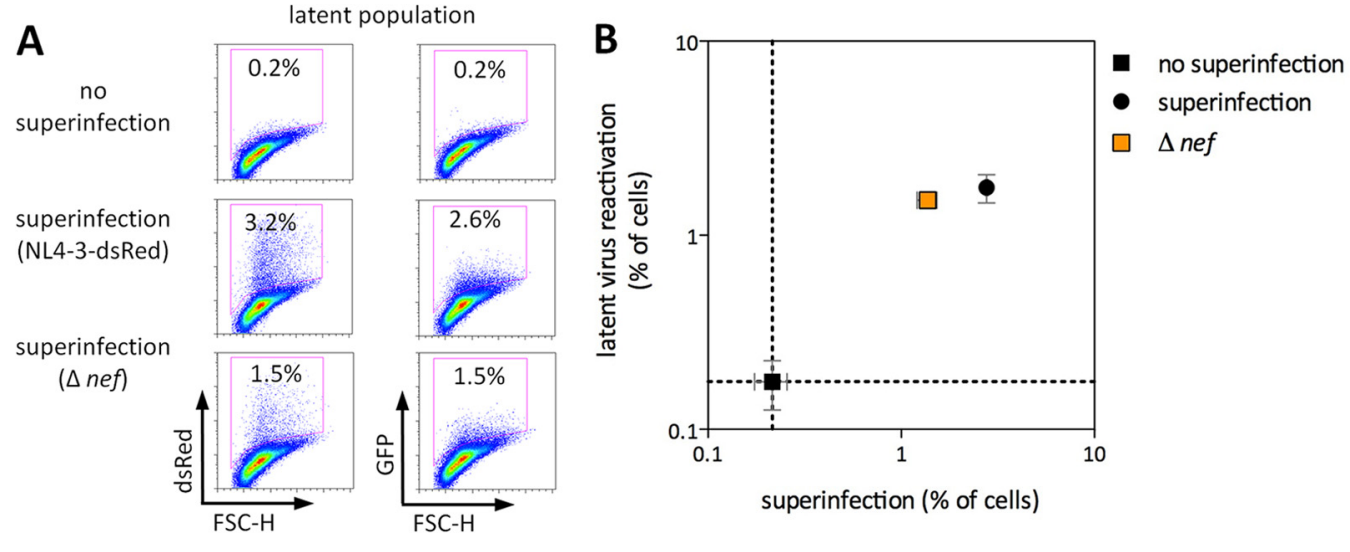

FIG 2 Superinfecting virus Nef is not required for latent virus reactivation. Uninfected or latently infected Jurkat cells were superinfected with NL4-3-dsRed or NL4-3-dsRed- $\Delta$ nef. Representative results are shown in panel A, and the results of three independent experiments performed in triplicate are shown in panel B. dsRed represents superinfecting virus, and GFP represents latent virus. FSC-H, forward scatter height. Error bars represent SEM ( $n=3$ for error bar calculations).

ruses were reactivated at least as efficiently in the absence of $\mathrm{Nef}$ as with wt virus (Fig. 2), excluding a requirement for Nef in the reactivation of latent viruses by superinfection in our model.

Latent virus reactivation via superinfection requires expression of functional Tat by the superinfecting virus. It is reasonable to hypothesize that production of Tat by superinfecting viruses might be required for reactivation of latent viruses. Accordingly, we produced replication-competent reporter viruses that encode functional (wt), attenuated (H13L), or transactivation-negative $(\mathrm{C} 22 \mathrm{G})$ Tat. Infection of Jurkat cells with these viruses resulted in equivalent levels of integrated DNA, whereas the percentage of cells positive for Tat-dependent viral reporter gene expression followed the expected pattern of wt $>$ H13L $>$ C22G (Fig. 3A). This demonstrates that these viruses are equally functional for all steps up to and including integration and that any differences in latent virus reactivation following superinfection would be due to different Tat activities and not due to any defect in superinfection. These viruses were then used to superinfect latently infected cells (Fig. 3B and C). While superinfection with wt tat virus efficiently reactivated latent viruses, superinfection with attenuated tat virus resulted in a modest but statistically insignificant reactivation of latent virus. Latent virus reactivation was not detectable when transactivation-negative tat virus was used for superinfection. Of note, the level of superinfection achieved with wt tat virus here is lower than that in comparable infections shown in Fig. 1 and 2. This is due to the use of HeLa-tat cells for production of the viruses used here (necessary for the production of C22G tat viruses and used for $\mathrm{H} 13 \mathrm{~L}$ and wt tat viruses to ensure consistency) as opposed to virus production in 293T cells, used elsewhere in this study. Since HeLa-tat transfection produced relatively low viral titers, lower viral inputs were used for the subsequent superinfections. However, all comparisons made with these viruses are internal (i.e., wt versus $\mathrm{H} 13 \mathrm{~L}$ versus $\mathrm{C} 22 \mathrm{G}$ virus, all produced in HeLa-tat cells), and all were used at equal p24 infection levels. As a control for any secreted Tat that might result from the use of HeLa-tat cells for virus production, latently infected cells were incubated directly with HeLa-tat supernatant; no latent virus reactivation was observed in this case (Fig. $3 \mathrm{~B}$ and C).

Together, the results of Fig. 1 to 3 show that reactivation of latent viruses by superinfection requires gene expression of the superinfecting virus and, specifically, production of functional Tat. Linear regression analysis reveals a strong positive correlation $\left(r^{2}=0.97\right)$ between the extent of superinfection and the extent of latent virus reactivation (Fig. 3D).

Efficiency of latent virus reactivation following superinfection. Based on the above results, we reasoned that latent viruses would be reactivated by superinfection across a wide range of infection rates and that superinfection with viruses encoding H13L Tat might also reactivate latent viruses if higher superinfection rates were achieved. Therefore, latently infected cells were superinfected with either wt or H13L tat viruses (both produced in 293T cells) using a 32-fold range of superinfecting virus inocula (Fig. $4 \mathrm{~A})$. DRV $(1 \mu \mathrm{M})$ was added to limit infection to a single round. As expected, latent viruses were reactivated across a wide range of superinfecting virus input levels when wt tat viruses were used (Fig. 4B), and there was a strong positive correlation $\left(r^{2}=0.98\right)$ between the extent of superinfection and the extent of latent virus reactivation. One-way ANOVA and Dunnett's multiple-comparison posttest indicated that the reactivation of latent viruses was statistically significant $(P<0.0001)$ for all superinfection input levels. Interestingly, latent viruses were also reactivated when H13L tat viruses were used for superinfection (Fig. 4C) $\left(r^{2}=\right.$ 0.88). One-way ANOVA and Dunnett's multiple-comparison posttest indicated that the reactivation of latent viruses was statistically significant $(P<0.0001)$ at the two highest superinfection input levels, while a nonsignificant reactivation was observed for lower superinfection levels. This also provides additional support for our above finding that latent virus reactivation following superinfection requires Tat function.

Latent HIV-1 can be reactivated by superinfection in unstimulated primary CD4 T cells. To test our hypothesis in a more physiologically relevant system, we used a primary cell model of HIV-1 latency that involves direct infection of unstimulated CD4 T cells. In this model, latency is established in multiple CD4 T-cell subsets, including naive, central memory, and transitional memory cells (37). Furthermore, CD4 T cells are cultured in the absence of cytokines, such as IL-2, and are infected shortly after isolation, preserving the in vivo distribution of CD4 T-cell subsets. The authors of this model also showed that infection of freshly isolated CD4 $\mathrm{T}$ cells gave near- 


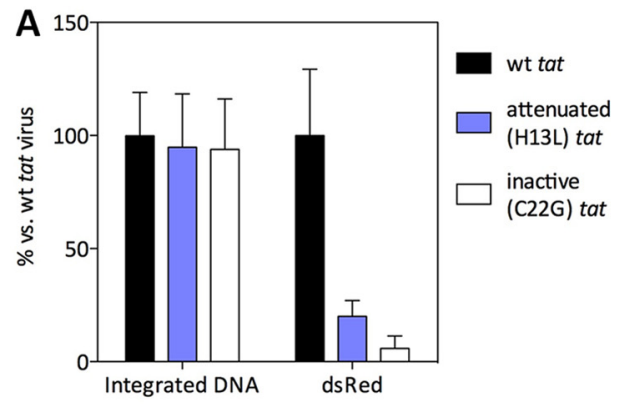

B

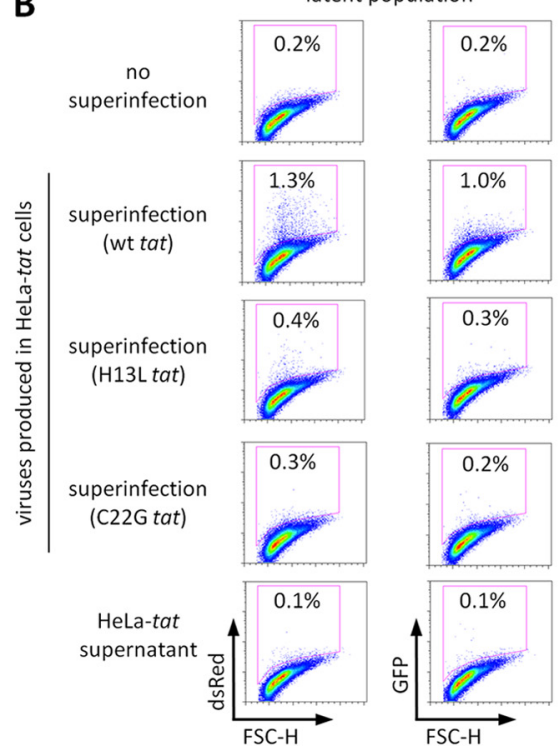

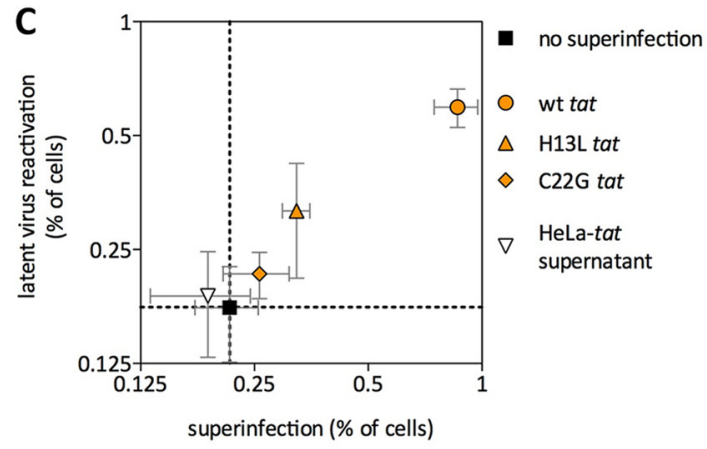

D

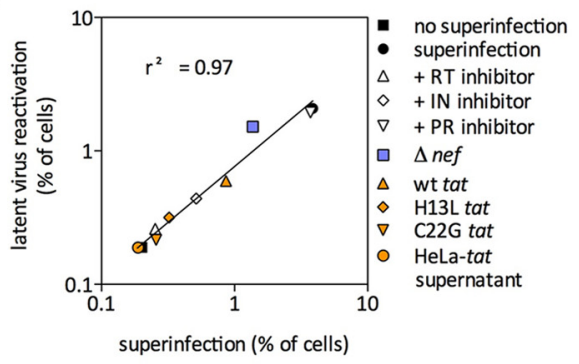

FIG 3 Latent virus reactivation via superinfection requires expression of functional Tat by the superinfecting virus. (A) wt, attenuated (H13L), or inactivated $(\mathrm{C} 22 \mathrm{G})$ tat viruses were produced by transfection of HeLa-tat cells and were then used to infect Jurkat cells in the presence of $1 \mu \mathrm{M}$ DRV to prevent reinfection. Levels of integrated viral DNA were measured by Alu-gag qPCR, while infectivity was determined by flow cytometry for virus-encoded dsRed. (B and C) Latently infected Jurkat cells were superinfected with NL4-3-dsRed (wt or H13L or C22G tat) or were treated with HeLa-tat supernatant as a control for any secreted Tat present in the superinfecting virus inoculum. FSC-H, forward scatter height. Representative results are shown in panel B, and the results of three independent experiments performed in triplicate are shown in panel C. (The axes in panel C are $\log _{2}$ rather than $\log _{10}$.) dsRed indicates superinfecting virus, and GFP represents latent virus. (D) Summary of the superinfection experiments shown in Fig. 1 to 3. Linear regression analysis was used to test for any correlation between superinfection and latent virus reactivation. Error bars represent SEM ( $n=3$ for error bar calculations).

identical results compared to infection of more extensively purified resting memory cells, which is likely because activated CD4 $\mathrm{T}$ cells in peripheral blood are present at only low frequency. Additionally, the latent viruses generated in this model respond to reactivating compounds with the same patterns observed for ex vivo-treated patient cells (37). Although some productively infected cells were also generated, spreading infection was prevented by a protease inhibitor.

We first assessed the purity and activation status of CD4 T cells isolated from multiple donors. The vast majority (typically $\sim 97 \%$ ) of cells expressed both CD3 and CD4, but they did not express the activation marker CD69 (<1\%) (Fig. 5B). Additionally, these cells were small and were nondividing, consistent with their being resting CD4 T cells. Isolated CD4 T cells from individual donors were infected with replication-competent dsRedencoding reporter viruses, in the presence of $1 \mu \mathrm{M}$ protease inhibitor DRV to prevent spreading infection. Across a wide range of infecting virus levels ( $25 \mathrm{ng}$ to $400 \mathrm{ng}$ p24 per million cells), infec- tion with attenuated $(\mathrm{H} 13 \mathrm{~L})$ tat virus resulted in higher levels of silencing than infection with wt tat virus, and postintegration, latent viruses were reactivated in all cases by treatment with antiCD3/CD28 beads in the presence of $10 \mu \mathrm{M}$ RAL (data not shown). Since the ratio of silent to active viruses was greater for attenuated tat virus infections (Fig. 5B) (data not shown), we used an attenuated tat reporter virus to address our hypothesis in this primary cell model (Fig. 5A).

Next, latency was established in primary cells of multiple donors, and these cells were superinfected with a GFP reporter virus (in the presence of $1 \mu \mathrm{M} \mathrm{DRV}$ ) to assess latent virus reactivation (Fig. 5B to D). The results of Fig. 5D to E show that superinfection led to a modest but significant reactivation of latent viruses in cells from nine individual donors (mean $\sim 30 \%$ increase in virus-expressing cells; $P=0.001$ ). Due to the low overall infection rates achievable in unstimulated primary CD4 T cells, higher rates of superinfection and latent virus reactivation might be unlikely to occur. Nonetheless, these data indicate that, similarly to Jurkat 


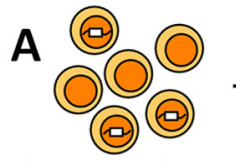

latent population (NL4-3- $\Delta e n v-E G F P-$ tat $-\mathrm{H} 13 \mathrm{~L})$
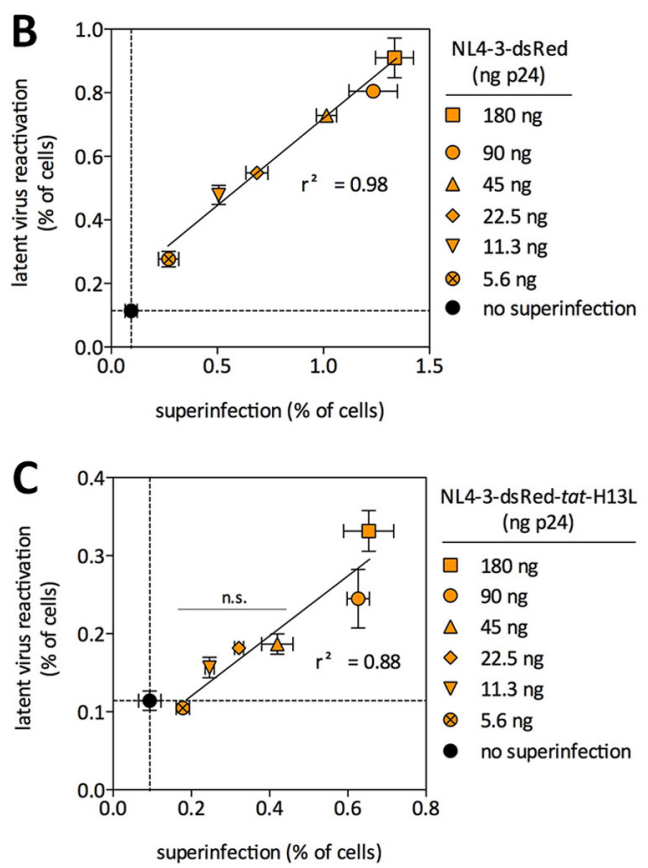

FIG 4 Efficiency of latent virus reactivation following superinfection. (A) Schematic representation of the experimental design. (B and C) Latently infected cells were superinfected with a wide range of NL4-3-dsRed viruses, encoding wt or H13L Tat. The indicated superinfection inoculum levels (ng p24) are per 75,000 cells. DRV $(1 \mu \mathrm{M})$ was added immediately after superinfection to limit viruses to a single round of replication. Linear regression analysis was used to test for any correlation between superinfection and latent virus reactivation. One-way ANOVA indicated that the reactivation of latent viruses was statistically significant $(P<0.0001)$ for both wt and H13L tat superinfections. Dunnett's multiple-comparison posttest was used to determine which conditions led to a statistically significant latent virus reactivation, compared to mock-superinfected latently infected cells ("no superinfection"). All conditions were statistically significant in panel B, while the two highest superinfection input levels were statistically significant in panel C. Error bars represent SEM ( $n=3$ for error bar calculations). The results of three independent experiments performed in duplicate are shown.

cells, latent viruses can be reactivated from unstimulated primary CD4 T cells by superinfection.

Drug-resistant latent viruses are reactivated by superinfection with other drug-resistant viruses. We next wished to determine whether reactivated latent viruses could contribute to the generation of recombinants. Latent Jurkat populations were established, in which the latent virus encodes the RT drug resistance mutation $\mathrm{K} 103 \mathrm{~N}$, which confers resistance to nonnucleoside reverse transcriptase inhibitors (NNRTIs), including EFV (Fig. 6B). To facilitate the identification of potential recombinants, the latent viruses also contained a noncoding restriction site change that removes an SbfI site $(\Delta$ SbfI) located $\sim 20$ nucleotides from the $\mathrm{K} 103 \mathrm{~N}$ mutation. K103N latent populations were superinfected with a dsRed-encoding drug-resistant reporter virus that encodes the RT mutation M184V, which provides for resistance to nucleoside RT inhibitors (NRTIs), including emtricitabine (FTC). The superinfecting virus also contained a noncoding restriction site change that removed an MboI site $(\Delta \mathrm{MboI})$ located $\sim 20$ nucleotides from the M184V mutation (Fig. 6A). As demonstrated in Fig. $6 \mathrm{C}$ to D, superinfection of K103N latent populations with M184V virus led to reactivation of drug-resistant latent viruses.

Reactivated latent viruses can recombine with superinfecting viruses, which can contribute to the development of multidrug-resistant recombinants. To determine whether recombination would occur between reactivated latent viruses and superinfecting viruses, supernatants of superinfected latent cells (which are expected to include some heterozygous virions [ $\Delta$ SbfI K103N/M184V $\Delta$ MboI]) were collected 3 days after superinfection and used for new infections (Fig. 6A). After $20 \mathrm{~h}$ (a time sufficient for the completion of reverse transcription but prior to the next round of viral replication [39]), EFV and FTC were added together at a range of concentrations to select for potential recombinants. This will select for only a small fraction of recombinant viruses: i.e., only those in which recombination occurred between amino acid positions 103 and 184 of RT and in the correct orientation to maintain both resistance mutations. Following addition of RT inhibitors, cultures were maintained for 6 days, and $\sim 1 \mathrm{~kb}$ of RT was then amplified by RT-PCR from supernatant viral genomic RNA.

Two approaches were used for the identification of recombinant viruses. First, RT amplicons were subject to double-restriction enzyme digestion with Sbfl and MboI, making use of the noncoding restriction site changes introduced into each virus. As shown in Fig. 6E (left), recombinant but not parental viruses are expected to result in both bands a and c. Recombinant viruses were detected in many but not all biological replicates across a range of drug-selective pressures, with representative results shown in Fig. 6E (right). Lanes 11, 13, and 14 (showing bands a, c, $\mathrm{d}$, and e) represent a mixture of recombinant and superinfecting viruses. In contrast, only superinfecting virus was present following infection of Jurkat cells (lanes 7 and 8) or of latent populations with no drug-selective pressure (lane 10). Comparison of the intensities of band a across different lanes gives an approximation of the overall level of virus present, since both superinfecting and recombinant viruses contribute to band a. (For example, lane 12 represents a lower level of virus than lane 11,13 , or 14 , consistent with the absence of recombinant viruses despite drug-selective pressure in that sample).

Second, bulk sequencing was used to estimate the proportion of recombinants in each sample. Recombinant viruses were only considered to be present when mathematically necessary. For example, if a population was $40 \% \Delta$ SbfI K103N and $90 \% \mathrm{M} 184 \mathrm{~V}$ $\Delta$ MboI, then at least $30 \%$ of the population must be recombinant viruses (where $\Delta$ Sbfl, K103N, and M184V $\Delta \mathrm{MboI}$ are on the same genomic RNA). If all mutations were present at $<50 \%$, the population was not considered to contain recombinants. The presence of the $\Delta$ SbfI and $\Delta \mathrm{MboI}$ mutations additionally confirms that recombinants are genuine, as opposed to the de novo acquisition of resistance mutations by either parental virus. As shown in Fig. 6F, multidrug-resistant recombinant viruses resulted from superinfection of latently infected cells in many but not all biological replicates. Since levels of recombinants increase with longer times in culture (in the presence of EFV plus FTC), the specific 


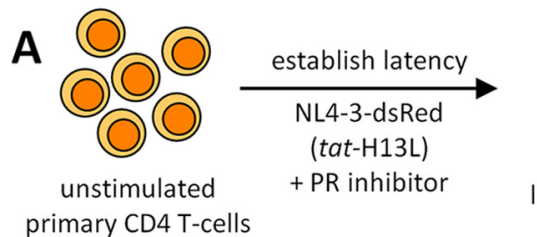

\section{B}

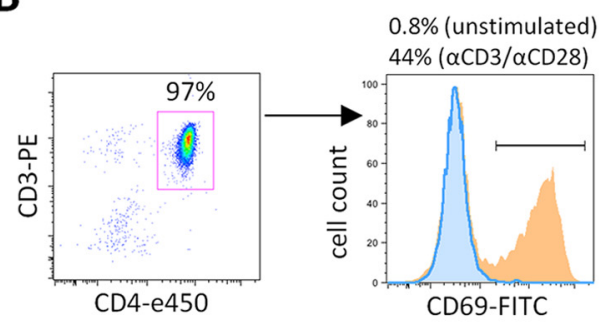

uninfected
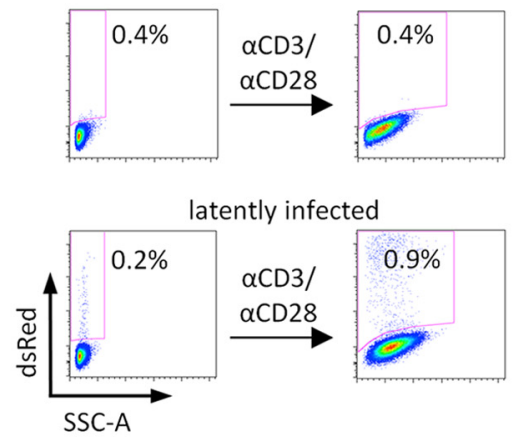

C

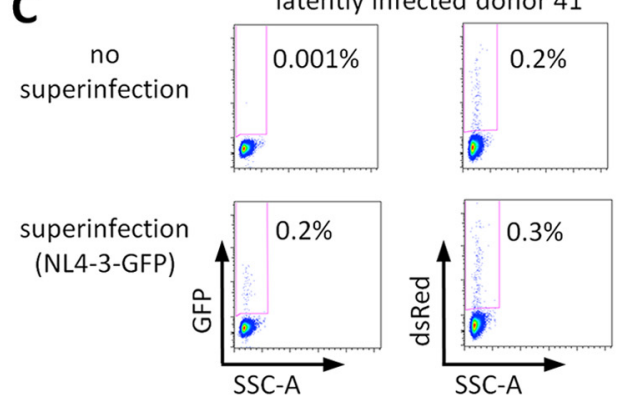

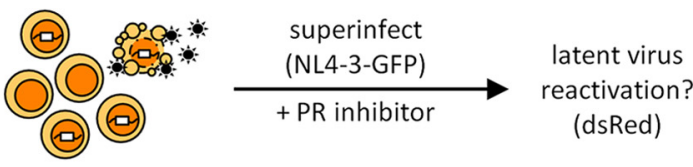

latent population
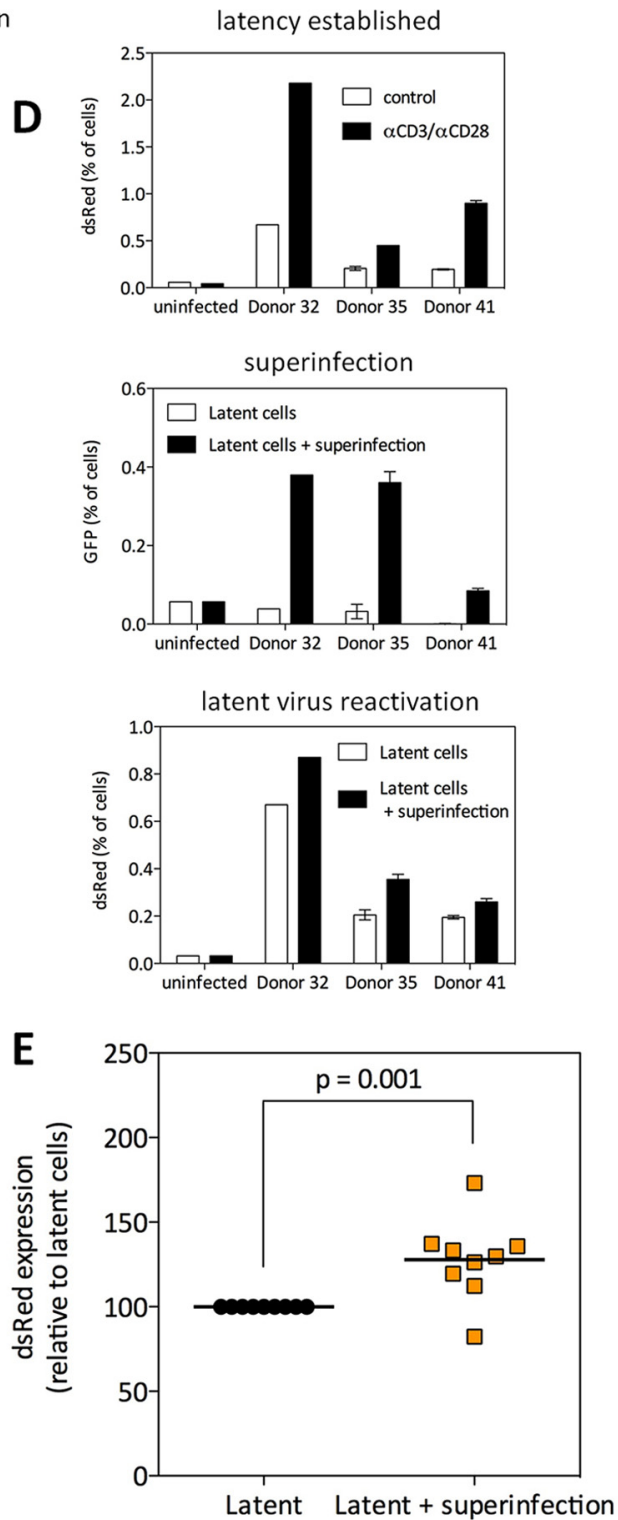

FIG 5 Superinfection of latently infected primary CD4 T cells leads to reactivation of latent virus. (A) Schematic representation of the experimental approach. (B) Isolated CD4 T cells were stained with anti-CD3-PE, anti-CD4-e450, and anti-CD69-FITC to determine purity and activation status; one representative donor is shown. In the histogram, the portion outlined and shaded blue depicts freshly isolated CD4 T cells, and the portion shaded orange depicts CD4 T cells incubated for $24 \mathrm{~h}$ with anti-CD3/CD28 beads (1:1 ratio) to induce T-cell activation. Latency was established using NL4-3-dsRed (tat $\mathrm{H} 13 \mathrm{~L}$ ) and is shown for one of nine donors. SSC-A, side scatter area. (C) Superinfection of latently infected cells led to latent virus reactivation; dsRed represents latent virus, and GFP represents superinfecting virus. One of nine donors is shown. (D) Three days after infection, cells were incubated with anti-CD3/CD28 beads (1:1 ratio) to determine the number of latent viruses (top panel) or were superinfected by spinoculation with GFP-expressing virus (or spinoculated with RPMI only as a control [middle panel]). The extent of latent virus reactivation was determined 3 days after superinfection (bottom panel). (E) The results from nine individual donors are shown. The percentage of dsRed-expressing cells (in the absence of superinfection) for each donor was set at $100 \%$, and the percentage of dsRedexpressing cells following superinfection with GFP virus is depicted.

percentages depicted are not themselves important. Rather, the presence versus absence of recombinants should be noted. No recombinants were detected following infection of Jurkat cells or following superinfection of latently infected cells in the absence of drug-selective pressure. Together, these results demonstrate that latent viruses can serve as a source for recombination, which might contribute to the emergence of multidrug-resistant recombinants. 


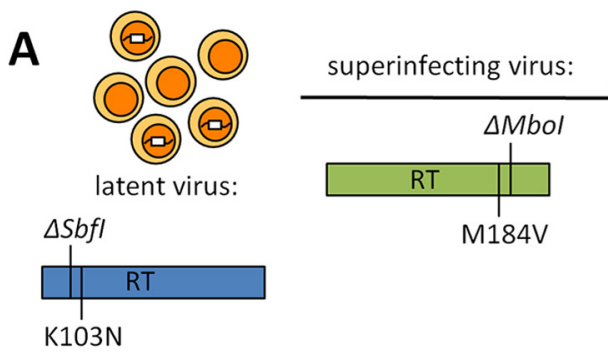

B

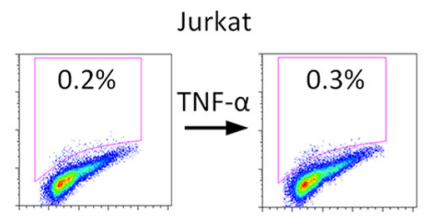

K103N latent population
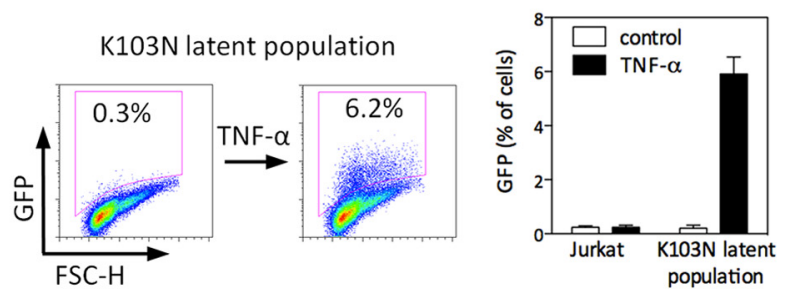

C

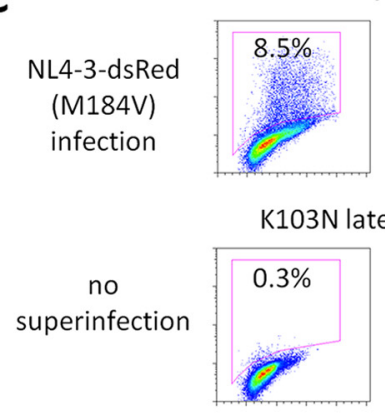

Jurkat
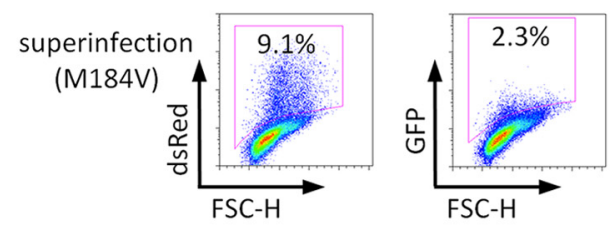

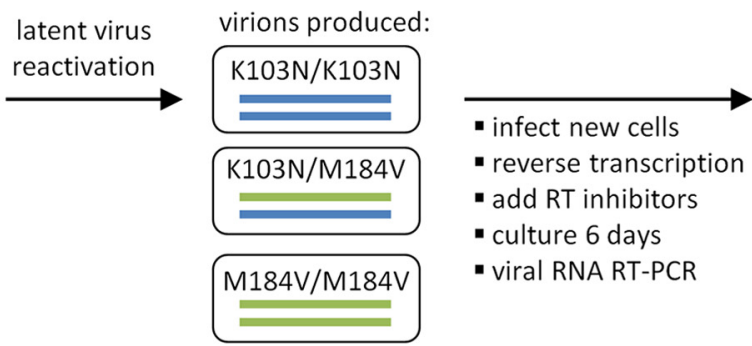

D

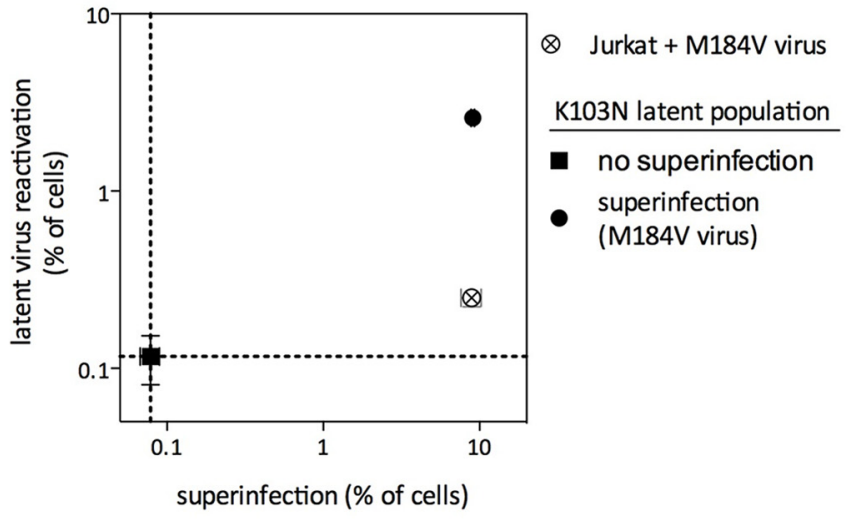

potential

recombinant:

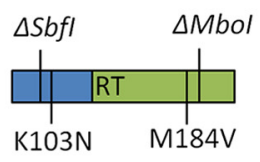

superinfection (\% of cells)

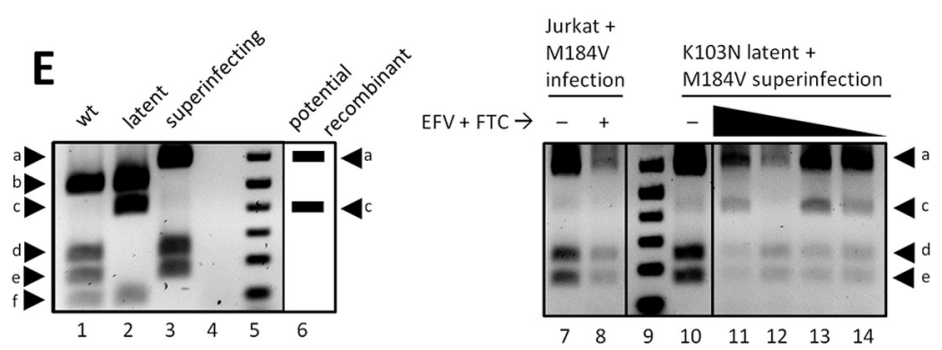

$\mathbf{F}$

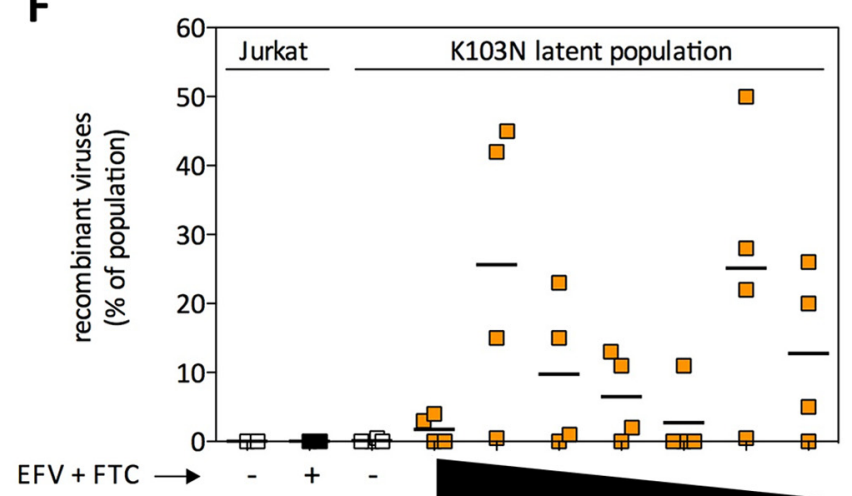

FIG 6 Drug-resistant latent viruses are reactivated by superinfection, can recombine with superinfecting viruses, and can contribute to the development of multidrug-resistant recombinants. (A) Schematic representation of the experimental design. (B) Characterization of the drug-resistant latent virus population used in these experiments. FSC-H, forward scatter height. Results of three independent experiments performed in duplicate are shown. (C and D) Uninfected or latently infected Jurkat cells were superinfected with NL4-3-dsRed-RT(M184V/DMboI). Representative results are shown in panel C, and the results from three independent experiments performed in triplicate are shown in panel D. dsRed represents superinfecting virus, and GFP represents latent virus. Error bars represent SEM ( $n=3$ for error bar calculations). (E) (Left) Plasmids representing wt, latent, or superinfecting viruses (lanes 1 to 3 ) were double digested with MboI and SbfI and run on agarose gels. Lane 4, empty; lane 5, DNA ladder. The presence of bands a and c in the same lane would indicate a recombinant virus derived from both the latent and superinfecting viruses (lane 6). (Right) RT-PCR products from supernatants of one representative experiment, as depicted in panel A, were double digested with MboI and Sbfl. Lanes 7 and 8, infection of Jurkat cells; lane 9, DNA ladder; lanes 10 to 14, superinfection of latently infected cells. As described in the Results section, recombinant viruses are represented in lanes 11, 13, and 14, but not lane 12 . Lanes 7 to 14 are from the same experiment and were run on the same gel. (F) Results of sequence analysis from two independent experiments performed in duplicate are shown. The recombinant virus is $\Delta$ Sbfl K103N M184V $\Delta$ MboI on the same genomic RNA. The highest drug concentrations applied were $20 \mathrm{nM}$ EFV plus $16 \mu \mathrm{M}$ FTC, while the lowest drug concentrations were $2.5 \mathrm{nM}$ EFV plus $250 \mathrm{nM}$ FTC. 


\section{DISCUSSION}

Latent virus reactivation might occur by superinfection of latently infected cells (33). Although it has been suggested that latent viruses might contribute to recombination in vivo $(25,34)$, this process has not been experimentally characterized. In this study, we asked whether latent viruses would be reactivated when their host cells are superinfected, and if so, whether they could contribute to the generation of recombinants. We demonstrated that superinfection of latently infected cells led to latent virus reactivation (Fig. 1), although we found no evidence for gp120 (Fig. 1) or Nef (Fig. 2) being required for this process in our Jurkat latency model. Inhibitors targeting different stages of viral replication were used to demonstrate that latent virus reactivation required gene expression of the superinfecting virus (Fig. 1), and use of functional, attenuated, or inactivated tat viruses demonstrated that latent virus reactivation required the activity of newly expressed Tat by the superinfecting virus (Fig. 3). Superinfection using wt or H13L tat viruses led to reactivation of latent viruses across a wide range of superinfection levels (Fig. 4). Superinfection of latently infected primary CD4 T cells also led to reactivation of latent viruses (Fig. 5). Finally, drug-resistant latent viruses were subject to reactivation by superinfection in Jurkat cells (Fig. $6 \mathrm{~A}$ to $\mathrm{D})$, which led to the generation of multidrug-resistant recombinants under selective pressure (Fig. 6E and F).

Lentiviruses, including HIV-1 have evolved various strategies to downregulate cell surface CD4, which might serve to impair immune recognition of infected cells and/or to limit cellular superinfection in a phenomenon referred to as superinfection immunity $(35,60,61)$. Although CD4 downregulation can decrease superinfection rates (35), this effect is not absolute, and others have observed minimal interference with superinfection (26). Regardless of the magnitude of superinfection immunity, we were interested in superinfection of latently infected cells. Since latent viruses express little or no viral gene products, neither CD4 downregulation nor superinfection immunity would be expected.

Most clinically relevant latent viruses are found in resting CD4 T cells. This implies that superinfection of latently infected cells in vivo would require infection of resting cells, which is much less efficient than infection of activated cells. Nonetheless, infection of resting cells does occur both in vitro and in vivo (reviewed in references 3 and 62). Furthermore, infection of phenotypically resting CD4 T cells is enhanced in chemokine- or cytokine-rich environments, such as secondary lymphoid tissues $(22,63-67)$ where the majority of lymphocytes - including multiply infected cellsreside, and several studies have reported that pretreatment of resting CD4 T cells with various chemokines increases subsequent infection rates (68-70).

Reactivation of latent viruses by superinfection (Fig. 1 to 4 ) results in cells expressing two genetically distinct viral genomes. Notably, HIV-1 has a much higher effective rate of recombination than some other retroviruses, such as murine leukemia virus (MLV). This is not due to higher rates of RT template switching, but rather to higher rates of heterozygous genomic RNA dimerization and packaging $(25,71,72)$. The segregation of HIV-1 but not MLV genomic RNA molecules into assembling virions is effectively a random process, and there is now direct physical evidence that heterozygous HIV-1 virions are produced according to a Hardy-Weinberg equilibrium (73). Furthermore, it has been estimated that nearly all HIV-1 virions undergo recombination dur- ing reverse transcription, as opposed to only a subpopulation of viruses $(26,72,74)$. It has also been suggested that superinfection contributes to recombination to a much greater extent than does cell-to-cell transmission, on the assumption that multiple infection by cell-to-cell transmission involves genetically identical virions (23). Regardless of the pathways of infection through which recombinant viruses arise, their evolutionary success is apparent given the global abundance of CRFs. More direct examples of the success of recombinants are shown by studies in which rhesus macaques were inoculated with two simian immunodeficiency virus (SIV) strains, each deleted in one or more accessory genes. In these studies, recombinants emerged as the dominant quasispecies in most macaques $(31,32)$. In settings of highly active antiretroviral therapy (HAART), the selective advantages of multidrugresistant viruses might be even greater than for these accessory gene-deleted lentiviruses.

Previous studies have examined superinfection of cell lines harboring defective or latent viruses, although not in the same context as explored here. The authors of one study infected the U1 and $\mathrm{ACH}-2$ cell lines (which harbor latent or defective proviruses) or their parental cell lines with HIV-1 that was pseudotyped with an amphotropic MLV envelope (75). In that study, superinfection was used as a tool to uncover cellular determinants of viral latency in $\mathrm{U} 1$ and ACH-2 cells and provided useful insights into HIV-1 latency at a time when little was known in that regard. However, latent virus reactivation and subsequent recombination were not addressed. A second study demonstrated recombination when a cell line chronically infected with a Vpr-deleted provirus was superinfected with other accessory gene-deleted viruses (76). More recently, our group has demonstrated recombination following superinfection of a cell line chronically infected with a multidrugresistant virus, although the cell line carried an envelope-defective virus rather than a latent virus (77). Another study recently demonstrated that coinfection with distinct reporter viruses led to higher than expected levels of double-positive cells and that this required Tat (78). This likely indicates that Tat expression from one coinfecting virus is sufficient to drive expression of both viral genomes, potentially limiting the earliest events involved in the establishment of latency. In the present study, we have used populations of both Jurkat cells and unstimulated primary CD4 T cells, each harboring latent viral genomes across diverse integration sites. Of note, the latent viruses used here encode H13L Tat that attenuates its activity by decreasing Tat-P-TEFb interactions. This is reminiscent of the enrichment of attenuated tat viruses that was identified in resting CD4 T cells of patients on suppressive therapy, where those tat mutations also caused decreased affinity for P-TEFb (79). Finally, one study showed that coinfection of a $\mathrm{T}$-cell line with two distinct drug-resistant viruses led to the emergence of multidrug-resistant recombinants following passage in cell culture under selective conditions (80).

While many of the same mechanisms appear to govern the establishment and maintenance of latency in Jurkat cells and primary cells $(3,81)$, their intracellular environments exhibit important differences. Thus, our examination of the effect of gp120 on latent virus reactivation (Fig. 1) might not be applicable to latency in primary resting cells, whose activation state is unlikely to be represented by Jurkat cells. Similarly, this issue might apply to our examination of the role of Nef in latent virus reactivation (Fig. 2). If anything, however, our results might suggest a modest inhibitory effect of Nef on latent virus reactivation in Jurkat cells (Fig. 2B 
and $3 \mathrm{D}$; compare the $\Delta n e f$ data point to the linear regression line), although this is purely speculative. These differences notwithstanding, our results indicate that latent viruses can be reactivated by superinfection in both Jurkat cells and primary CD4 T cells. It is worth discussing our use of an NRTI-resistant virus in the recombination experiments presented in Fig. 6, since some NRTI resistance mutations alter recombination rates. However, the M184V mutation used here has only a minor effect on RT template-switching rates (82). Additionally, it has been shown that recombination occurs at similar frequencies in both Jurkat cells and primary cells (26).

Recombination is expected to occur whenever there is ongoing replication. While two recent studies have provided evidence for ongoing HIV-1 replication during suppressive HAART $(83,84)$, the general consensus is that ongoing replication does not occur in most HAART-treated patients (85-88). Nonetheless residual viremia is present in most HAART-treated individuals, which likely arises from reactivation of latent viruses, and a recent study demonstrated that residual viremia during long-term suppressive HAART was infectious (89). This suggests that new rounds of replication could occur during periods of low drug adherence or treatment interruption or even during adherent treatment if the residual virus was drug resistant. Superinfection of latently infected cells might be expected to occur regularly in untreated patients and could also occur during HAART as a result of infectious residual viremia, regardless of whether the residual viremia originated from activation of individual latent viruses, low-level ongoing replication, or viral rebound following treatment failure. As demonstrated here, reactivated latent viruses are capable of undergoing recombination. Recombination is widely acknowledged to increase viral evolution in individual patients $(24,25,34,90$, 91 ), often though not always accelerating the emergence of multidrug resistance (92-94). Since all viral quasispecies, including drug-resistant viruses, can be latently archived (11-15), reactivation of latent viruses by superinfection or other means could provide for the emergence or spread of replicatively fit viruses in the face of strong selective pressures.

\section{ACKNOWLEDGMENTS}

This work was supported by grants from the Canadian Institutes of Health Research (CIHR). D.A.D. is the recipient of a doctoral research award from CIHR. Work by D.A.D. was performed in partial fulfillment of the requirements for the Ph.D. degree from the Faculty of Graduate Studies and Research, McGill University, Montréal, Québec, Canada.

We thank Maureen Oliveira, Susan Colby-Germinario, and Cesar Collazos for providing technical assistance. We also thank Christian Young of the Lady Davis Institute flow cytometry facility for aid with flow cytometry analysis. pBR-NL4-3-IRES-dsRed and derivatives were kindly provided by J. Münch and F. Kirchhoff.

\section{REFERENCES}

1. Chun TW, Engel D, Berrey MM, Shea T, Corey L, Fauci AS. 1998. Early establishment of a pool of latently infected, resting CD4 $(+)$ T cells during primary HIV-1 infection. Proc. Natl. Acad. Sci. U. S. A. 95:8869-8873.

2. Archin NM, Vaidya NK, Kuruc JD, Liberty AL, Wiegand A, Kearney MF, Cohen MS, Coffin JM, Bosch RJ, Gay CL, Eron JJ, Margolis DM, Perelson AS. 2012. Immediate antiviral therapy appears to restrict resting CD4+ cell HIV-1 infection without accelerating the decay of latent infection. Proc. Natl. Acad. Sci. U. S. A. 109:9523-9528.

3. Donahue DA, Wainberg MA. 2013. Cellular and molecular mechanisms involved in the establishment of HIV-1 latency. Retrovirology 10:11. doi: 10.1186/1742-4690-10-11.

4. Hakre S, Chávez L, Shirakawa K, Verdin E. 2012. HIV latency: experi- mental systems and molecular models. FEMS Microbiol. Rev. 36:706716.

5. Siliciano RF, Greene WC. 2011. HIV latency. Cold Spring Harb. Perspect. Med. 1:a007096. doi:10.1101/cshperspect.a007096.

6. Mbonye U, Karn J. 2011. Control of HIV latency by epigenetic and non-epigenetic mechanisms. Curr. HIV Res. 9:554-567.

7. Abbas W, Herbein G. 2012. Molecular understanding of HIV-1 latency. Adv. Virol. 2012:574967. doi:10.1155/2012/574967.

8. Geeraert L, Kraus G, Pomerantz RJ. 2008. Hide-and-seek: the challenge of viral persistence in HIV-1 infection. Annu. Rev. Med. 59:487-501.

9. Chun T-W, Fauci AS. 2012. HIV reservoirs: pathogenesis and obstacles to viral eradication and cure. AIDS 26:1261-1268.

10. Han Y, Wind-Rotolo M, Yang H-C, Siliciano JD, Siliciano RF. 2007. Experimental approaches to the study of HIV-1 latency. Nat. Rev. Microbiol. 5:95-106.

11. Persaud D, Pierson T, Ruff C, Finzi D, Chadwick KR, Margolick JB, Ruff A, Hutton N, Ray S, Siliciano RF. 2000. A stable latent reservoir for HIV-1 in resting CD4(+) T lymphocytes in infected children. J. Clin. Invest. 105:995-1003.

12. Ruff CT, Ray SC, Kwon P, Zinn R, Pendleton A, Hutton N, Ashworth R, Gange S, Quinn TC, Siliciano RF, Persaud D. 2002. Persistence of wild-type virus and lack of temporal structure in the latent reservoir for human immunodeficiency virus type 1 in pediatric patients with extensive antiretroviral exposure. J. Virol. 76:9481-9492.

13. Monie D, Simmons RP, Nettles RE, Kieffer TL, Zhou Y, Zhang H, Karmon S, Ingersoll R, Chadwick K, Zhang H, Margolick JB, Quinn TC, Ray SC, Wind-Rotolo M, Miller M, Persaud D, Siliciano RF. 2005. A novel assay allows genotyping of the latent reservoir for human immunodeficiency virus type 1 in the resting $\mathrm{CD} 4+\mathrm{T}$ cells of viremic patients. J. Virol. 79:5185-5202.

14. Lambotte O, Chaix M-L, Gubler B, Nasreddine N, Wallon C, Goujard C, Rouzioux C, Taoufik Y, Delfraissy J-F. 2004. The lymphocyte HIV reservoir in patients on long-term HAART is a memory of virus evolution. AIDS 18:1147-1158.

15. Verhofstede C, Noë A, Demecheleer E, De Cabooter N, Van Wanzeele F, Van Der Gucht B, Vogelaers D, Plum J. 2004. Drug-resistant variants that evolve during nonsuppressive therapy persist in HIV-1-infected peripheral blood mononuclear cells after long-term highly active antiretroviral therapy. J. Acquir. Immune Defic. Syndr. 35:473-483.

16. Joos B, Fischer M, Kuster H, Pillai SK, Wong JK, Böni J, Hirschel B, Weber R, Trkola A, Günthard HF, Swiss HIV Cohort Study. 2008. HIV rebounds from latently infected cells, rather than from continuing lowlevel replication. Proc. Natl. Acad. Sci. U. S. A. 105:16725-16730.

17. Gratton S, Cheynier R, Dumaurier MJ, Oksenhendler E, Wain-Hobson S. 2000. Highly restricted spread of HIV-1 and multiply infected cells within splenic germinal centers. Proc. Natl. Acad. Sci. U. S. A. 97:1456614571.

18. Jung A, Maier R, Vartanian J-P, Bocharov G, Jung V, Fischer U, Meese E, Wain-Hobson S, Meyerhans A. 2002. Recombination: multiply infected spleen cells in HIV patients. Nature 418:144. doi:10.1038/418144a.

19. Josefsson L, King MS, Makitalo B, Brännström J, Shao W, Maldarelli F, Kearney MF, Hu W-S, Chen J, Gaines H, Mellors JW, Albert J, Coffin JM, Palmer SE. 2011. Majority of CD4 + T cells from peripheral blood of HIV-1-infected individuals contain only one HIV DNA molecule. Proc. Natl. Acad. Sci. U. S. A. 108:11199-11204.

20. Del Portillo A, Tripodi J, Najfeld V, Wodarz D, Levy DN, Chen BK. 2011. Multiploid inheritance of HIV-1 during cell-to-cell infection. J. Virol. 85:7169-7176.

21. Russell RA, Martin N, Mitar I, Jones E, Sattentau QJ. 27 May 2013. Multiple proviral integration events after virological synapse-mediated HIV-1 spread. Virology [Epub ahead of print.] doi:10.1016/j.virol.2013.05 .005 .

22. Rudnicka D, Feldmann J, Porrot F, Wietgrefe S, Guadagnini S, Prévost M-C, Estaquier J, Haase AT, Sol-Foulon N, Schwartz O. 2009. Simultaneous cell-to-cell transmission of human immunodeficiency virus to multiple targets through polysynapses. J. Virol. 83:6234-6246.

23. Dixit NM, Perelson AS. 2004. Multiplicity of human immunodeficiency virus infections in lymphoid tissue. J. Virol. 78:8942-8945.

24. Smyth RP, Davenport MP, Mak J. 2012. The origin of genetic diversity in HIV-1. Virus Res. 169:415-429.

25. Onafuwa-Nuga A, Telesnitsky A. 2009. The remarkable frequency of human immunodeficiency virus type 1 genetic recombination. Microbiol. Mol. Biol. Rev. 73:451-480. 
26. Levy DN, Aldrovandi GM, Kutsch O, Shaw GM. 2004. Dynamics of HIV-1 recombination in its natural target cells. Proc. Natl. Acad. Sci. U. S. A. 101:4204-4209.

27. Hemelaar J. 2013. Implications of HIV diversity for the HIV-1 pandemic. J. Infect. 66:391-400.

28. Günthard HF, Leigh-Brown AJ, D’Aquila RT, Johnson VA, Kuritzkes DR, Richman DD, Wong JK, D'Aquila RT. 1999. Higher selection pressure from antiretroviral drugs in vivo results in increased evolutionary distance in HIV-1 pol. Virology 259:154-165.

29. Nora T, Charpentier C, Tenaillon O, Hoede C, Clavel F, Hance AJ. 2007. Contribution of recombination to the evolution of human immunodeficiency viruses expressing resistance to antiretroviral treatment. J. Virol. 81:7620-7628.

30. Ray N, Harrison JE, Blackburn LA, Martin JN, Deeks SG, Doms RW. 2007. Clinical resistance to enfuvirtide does not affect susceptibility of human immunodeficiency virus type 1 to other classes of entry inhibitors. J. Virol. 81:3240-3250.

31. Wooley DP, Smith RA, Czajak S, Desrosiers RC. 1997. Direct demonstration of retroviral recombination in a rhesus monkey. J. Virol. 71: 9650-9653.

32. Kim E-Y, Busch M, Abel K, Fritts L, Bustamante P, Stanton J, Lu D, Wu S, Glowczwskie J, Rourke T, Bogdan D, Piatak M, Lifson JD, Desrosiers RC, Wolinsky S, Miller CJ. 2005. Retroviral recombination in vivo: viral replication patterns and genetic structure of simian immunodeficiency virus (SIV) populations in rhesus macaques after simultaneous or sequential intravaginal inoculation with SIVmac239 $\Delta v p x / \Delta v p r$ and

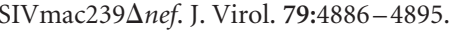

33. Berngruber TW, Weissing FJ, Gandon S. 2010. Inhibition of superinfection and the evolution of viral latency. J. Virol. 84:10200-10208.

34. Charpentier C, Nora T, Tenaillon O, Clavel F, Hance AJ. 2006. Extensive recombination among human immunodeficiency virus type 1 quasispecies makes an important contribution to viral diversity in individual patients. J. Virol. 80:2472-2482.

35. Wildum S, Schindler M, Münch J, Kirchhoff F. 2006. Contribution of Vpu, Env, and Nef to CD4 down-modulation and resistance of human immunodeficiency virus type 1-infected T cells to superinfection. J. Virol. 80:8047-8059.

36. Donahue DA, Kuhl BD, Sloan RD, Wainberg MA. 2012. The viral protein Tat can inhibit the establishment of HIV-1 latency. J. Virol. 86: 3253-3263.

37. Lassen KG, Hebbeler AM, Bhattacharyya D, Lobritz MA, Greene WC. 2012. A flexible model of HIV-1 latency permitting evaluation of many primary CD4 T-cell reservoirs. PLoS One 7:e30176. doi:10.1371/journal .pone.0030176.

38. Yu JJ, Wu TL, Liszewski MK, Dai J, Swiggard WJ, Baytop C, Frank I, Levine BL, Yang W, Theodosopoulos T, O'Doherty U. 2008. A more precise HIV integration assay designed to detect small differences finds lower levels of integrated DNA in HAART treated patients. Virology 379: $78-86$.

39. Donahue DA, Sloan RD, Kuhl BD, Bar-Magen T, Schader SM, Wainberg MA. 2010. Stage-dependent inhibition of HIV-1 replication by antiretroviral drugs in cell culture. Antimicrob. Agents Chemother. 54: 1047-1054.

40. Pearson R, Kim YK, Hokello J, Lassen K, Friedman J, Tyagi M, Karn J. 2008. Epigenetic silencing of human immunodeficiency virus (HIV) transcription by formation of restrictive chromatin structures at the viral long terminal repeat drives the progressive entry of HIV into latency. J. Virol. 82:12291-12303.

41. Weinberger LS, Burnett JC, Toettcher JE, Arkin AP, Schaffer DV. 2005. Stochastic gene expression in a lentiviral positive-feedback loop: HIV-1 Tat fluctuations drive phenotypic diversity. Cell 122:169-182.

42. Weinberger LS, Dar RD, Simpson ML. 2008. Transient-mediated fate determination in a transcriptional circuit of HIV. Nat. Genet. 40:466470.

43. Singh A, Weinberger LS. 2009. Stochastic gene expression as a molecular switch for viral latency. Curr. Opin. Microbiol. 12:460-466.

44. Tyagi M, Karn J. 2007. CBF-1 promotes transcriptional silencing during the establishment of HIV-1 latency. EMBO J. 26:4985-4995.

45. Tyagi M, Pearson RJ, Karn J. 2010. Establishment of HIV latency in primary $\mathrm{CD} 4+$ cells is due to epigenetic transcriptional silencing and P-TEFb restriction. J. Virol. 84:6425-6437.

46. Kim YK, Mbonye U, Hokello J, Karn J. 2011. T-cell receptor signaling enhances transcriptional elongation from latent HIV proviruses by acti- vating P-TEFb through an ERK-dependent pathway. J. Mol. Biol. 410: 896-916.

47. Mbonye UR, Gokulrangan G, Datt M, Dobrowolski C, Cooper M, Chance MR, Karn J. 2013. Phosphorylation of CDK9 at Ser175 enhances HIV transcription and is a marker of activated P-TEFb in CD4(+) T lymphocytes. PLoS Pathog. 9:e1003338. doi:10.1371/journal.ppat.1003338.

48. Cicala C, Arthos J, Censoplano N, Cruz C, Chung E, Martinelli E, Lempicki RA, Natarajan V, VanRyk D, Daucher M, Fauci AS. 2006. HIV-1 gp120 induces NFAT nuclear translocation in resting CD4+ Tcells. Virology 345:105-114.

49. Cicala C, Arthos J, Selig SM, Dennis G, Hosack DA, Van Ryk D, Spangler ML, Steenbeke TD, Khazanie P, Gupta N, Yang J, Daucher M, Lempicki RA, Fauci AS. 2002. HIV envelope induces a cascade of cell signals in non-proliferating target cells that favor virus replication. Proc. Natl. Acad. Sci. U. S. A. 99:9380-9385.

50. Missé D, Gajardo J, Oblet C, Religa A, Riquet N, Mathieu D, Yssel H, Veas F. 2005. Soluble HIV-1 gp120 enhances HIV-1 replication in nondividing CD4+ T cells, mediated via cell signaling and Tat cofactor overexpression. AIDS 19:897-905.

51. Davis CB, Dikic I, Unutmaz D, Hill CM, Arthos J, Siani MA, Thompson DA, Schlessinger J, Littman DR. 1997. Signal transduction due to HIV-1 envelope interactions with chemokine receptors CXCR4 or CCR5. J. Exp. Med. 186:1793-1798.

52. Vasiliver-Shamis G, Dustin ML, Hioe CE. 2010. HIV-1 Virological synapse is not simply a copycat of the immunological synapse. Viruses 2:1239-1260.

53. Kinter AL, Umscheid CA, Arthos J, Cicala C, Lin Y, Jackson R, Donoghue E, Ehler L, Adelsberger J, Rabin RL, Fauci AS. 2003. HIV envelope induces virus expression from resting $\mathrm{CD} 4+\mathrm{T}$ cells isolated from HIVinfected individuals in the absence of markers of cellular activation or apoptosis. J. Immunol. 170:2449-2455.

54. Shen L, Peterson S, Sedaghat AR, McMahon MA, Callender M, Zhang H, Zhou Y, Pitt E, Anderson KS, Acosta EP, Siliciano RF. 2008. Dose-response curve slope sets class-specific limits on inhibitory potential of anti-HIV drugs. Nat. Med. 14:762-766.

55. Sloan RD, Wainberg MA. 2011. The role of unintegrated DNA in HIV infection. Retrovirology 8:52. doi:10.1186/1742-4690-8-52.

56. Abraham L, Fackler OT. 2012. HIV-1 Nef: a multifaceted modulator of T cell receptor signaling. Cell Commun. Signal. 10:39. doi:10.1186/1478 -811X-10-39.

57. Landi A, Iannucci V, Nuffel AV, Meuwissen P, Verhasselt B. 2011. One protein to rule them all: modulation of cell surface receptors and molecules by HIV Nef. Curr. HIV Res. 9:496-504.

58. Simmons A, Aluvihare V, McMichael A. 2001. Nef triggers a transcriptional program in $\mathrm{T}$ cells imitating single-signal $\mathrm{T}$ cell activation and inducing HIV virulence mediators. Immunity 14:763-777.

59. Wu Y, Marsh JW. 2001. Selective transcription and modulation of resting T cell activity by preintegrated HIV DNA. Science 293:1503-1506.

60. Geleziunas R, Bour S, Wainberg MA. 1994. Cell surface downmodulation of CD4 after infection by HIV-1. FASEB J. 8:593-600.

61. Michel N, Allespach I, Venzke S, Fackler OT, Keppler OT. 2005. The Nef protein of human immunodeficiency virus establishes superinfection immunity by a dual strategy to downregulate cell-surface CCR 5 and CD4. Curr. Biol. 15:714-723.

62. Vatakis DN, Nixon CC, Zack JA. 2010. Quiescent T cells and HIV: an unresolved relationship. Immunol. Res. 48:110-121.

63. Li Q, Duan L, Estes JD, Ma Z-M, Rourke T, Wang Y, Reilly C, Carlis J, Miller CJ, Haase AT. 2005. Peak SIV replication in resting memory $\mathrm{CD} 4+\mathrm{T}$ cells depletes gut lamina propria $\mathrm{CD} 4+\mathrm{T}$ cells. Nature 434: $1148-1152$.

64. Unutmaz D, KewalRamani VN, Marmon S, Littman DR. 1999. Cytokine signals are sufficient for HIV-1 infection of resting human T lymphocytes. J. Exp. Med. 189:1735-1746.

65. Kinter A, Moorthy A, Jackson R, Fauci AS. 2003. Productive HIV infection of resting $\mathrm{CD} 4+\mathrm{T}$ cells: role of lymphoid tissue microenvironment and effect of immunomodulating agents. AIDS Res. Hum. Retroviruses 19:847-856.

66. Eckstein DA, Penn ML, Korin YD, Scripture-Adams DD, Zack JA, Kreisberg JF, Roederer M, Sherman MP, Chin PS, Goldsmith MA. 2001. HIV-1 actively replicates in naive CD4(+) T cells residing within human lymphoid tissues. Immunity 15:671-682.

67. Weissman D, Daucher J, Barker T, Adelsberger J, Baseler M, Fauci AS. 1996. Cytokine regulation of HIV replication induced by dendritic cell- 
CD4-positive T cell interactions. AIDS Res. Hum. Retroviruses 12:759_ 767.

68. Saleh S, Solomon A, Wightman F, Xhilaga M, Cameron PU, Lewin SR. 2007. CCR7 ligands CCL19 and CCL21 increase permissiveness of resting memory CD4+ T cells to HIV-1 infection: a novel model of HIV-1 latency. Blood 110:4161-4164.

69. Cameron PU, Saleh S, Sallmann G, Solomon A, Wightman F, Evans VA, Boucher G, Haddad EK, Sékaly R-P, Harman AN, Anderson JL, Jones KL, Mak J, Cunningham AL, Jaworowski A, Lewin SR. 2010. Establishment of HIV-1 latency in resting CD4 + T cells depends on chemokine-induced changes in the actin cytoskeleton. Proc. Natl. Acad. Sci. U. S. A. 107:16934-16939.

70. Saleh S, Wightman F, Ramanayake S, Alexander M, Kumar N, Khoury G, Pereira C, Purcell D, Cameron PU, Lewin SR. 2011. Expression and reactivation of HIV in a chemokine induced model of HIV latency in primary resting CD4 + T cells. Retrovirology 8:80. doi:10.1186/1742-4690 $-8-80$.

71. Zhuang J, Mukherjee S, Ron Y, Dougherty JP. 2006. High rate of genetic recombination in murine leukemia virus: implications for influencing proviral ploidy. J. Virol. 80:6706-6711.

72. Onafuwa A, An W, Robson ND, Telesnitsky A. 2003. Human immunodeficiency virus type 1 genetic recombination is more frequent than that of Moloney murine leukemia virus despite similar template switching rates. J. Virol. 77:4577-4587.

73. Chen J, Nikolaitchik O, Singh J, Wright A, Bencsics CE, Coffin JM, Ni N, Lockett S, Pathak VK, Hu W-S. 2009. High efficiency of HIV-1 genomic RNA packaging and heterozygote formation revealed by single virion analysis. Proc. Natl. Acad. Sci. U. S. A. 106:13535-13540

74. Rhodes T, Wargo H, Hu W-S. 2003. High rates of human immunodeficiency virus type 1 recombination: near-random segregation of markers one kilobase apart in one round of viral replication. J. Virol. 77:1119311200 .

75. Chen BK, Saksela K, Andino R, Baltimore D. 1994. Distinct modes of human immunodeficiency virus type 1 proviral latency revealed by superinfection of nonproductively infected cell lines with recombinant luciferase-encoding viruses. J. Virol. 68:654-660.

76. Kishi M, Tokunaga K, Zheng YH, Bahmani MK, Kakinuma M, Nonoyama M, Lai PK, Ikuta K. 1995. Superinfection of a defective human immunodeficiency virus type 1 provirus-carrying $\mathrm{T}$ cell clone with vif or vpu mutants gives cytopathic virus particles by homologous recombination. AIDS Res. Hum. Retroviruses 11:45-53.

77. Quan Y, Liang C, Brenner BG, Wainberg MA. 2009. Multidrug-resistant variants of HIV type 1 (HIV-1) can exist in cells as defective quasispecies and be rescued by superinfection with other defective HIV-1 variants. J. Infect. Dis. 200:1479-1483.

78. Brégnard C, Pacini G, Danos O, Basmaciogullari S. 2012. Suboptimal provirus expression explains apparent nonrandom cell coinfection with HIV-1. J. Virol. 86:8810-8820.

79. Yukl S, Pillai S, Li P, Chang K, Pasutti W, Ahlgren C, Havlir D, Strain M, Günthard H, Richman D, Rice AP, Daar E, Little S, Wong JK. 2009. Latently-infected CD4+ T cells are enriched for HIV-1 Tat variants with impaired transactivation activity. Virology 387:98-108.
80. Moutouh L, Corbeil J, Richman DD. 1996. Recombination leads to the rapid emergence of HIV-1 dually resistant mutants under selective drug pressure. Proc. Natl. Acad. Sci. U. S. A. 93:6106-6111.

81. Dahabieh MS, Ooms M, Simon V, Sadowski I. 2013. A doublefluorescent HIV-1 reporter shows that the majority of integrated HIV-1 is latent shortly after infection. J. Virol. 87:4716-4727.

82. Nikolenko GN, Svarovskaia ES, Delviks KA, Pathak VK. 2004. Antiretroviral drug resistance mutations in human immunodeficiency virus type 1 reverse transcriptase increase template-switching frequency. J. Virol. 78:8761-8770.

83. Buzón MJ, Massanella M, Llibre JM, Esteve A, Dahl V, Puertas MC, Gatell JM, Domingo P, Paredes R, Sharkey M, Palmer S, Stevenson M, Clotet B, Blanco J, Martinez-Picado J. 2010. HIV-1 replication and immune dynamics are affected by raltegravir intensification of HAARTsuppressed subjects. Nat. Med. 16:460-465.

84. Buzón MJ, Codoñer FM, Frost SDW, Pou C, Puertas MC, Massanella M, Dalmau J, Llibre JM, Stevenson M, Blanco J, Clotet B, Paredes R, Martinez-Picado J. 2011. Deep molecular characterization of HIV-1 dynamics under suppressive HAART. PLoS Pathog. 7:e1002314. doi:10.1371 /journal.ppat.1002314.

85. Eisele E, Siliciano RF. 2012. Redefining the viral reservoirs that prevent HIV-1 eradication. Immunity 37:377-388.

86. Johnston R, Barré-Sinoussi F. 2012. Controversies in HIV cure research. J. Int. AIDS Soc. 15:16. doi:10.1186/1758-2652-15-16.

87. Maldarelli F. 2011. Targeting viral reservoirs: ability of antiretroviral therapy to stop viral replication. Curr. Opin. HIV AIDS 6:49-56.

88. Evering TH, Mehandru S, Racz P, Tenner-Racz K, Poles MA, Figueroa A, Mohri H, Markowitz M. 2012. Absence of HIV-1 evolution in the gut-associated lymphoid tissue from patients on combination antiviral therapy initiated during primary infection. PLoS Pathog. 8:e1002506. doi: 10.1371/journal.ppat.1002506.

89. Sahu GK, Sarria JC, Cloyd MW. 2010. Recovery of replicationcompetent residual HIV-1 from plasma of a patient receiving prolonged, suppressive highly active antiretroviral therapy. J. Virol. 84:8348 -8352.

90. Bocharov G, Ford NJ, Edwards J, Breinig T, Wain-Hobson S, Meyerhans A. 2005. A genetic-algorithm approach to simulating human immunodeficiency virus evolution reveals the strong impact of multiply infected cells and recombination. J. Gen. Virol. 86:3109-3118.

91. Vijay NNV, Vasantika Ajmani R, Perelson AS, Dixit NM. 2008. Recombination increases human immunodeficiency virus fitness, but not necessarily diversity. J. Gen. Virol. 89:1467-1477.

92. Althaus CL, Bonhoeffer S. 2005. Stochastic interplay between mutation and recombination during the acquisition of drug resistance mutations in human immunodeficiency virus type 1. J. Virol. 79:13572-13578.

93. Arora P, Dixit NM. 2009. Timing the emergence of resistance to anti-HIV drugs with large genetic barriers. PLoS Comput. Biol. 5:e1000305. doi:10 .1371 journal.pcbi.1000305.

94. Carvajal-Rodríguez A, Crandall KA, Posada D. 2007. Recombination favors the evolution of drug resistance in HIV-1 during antiretroviral therapy. Infect. Genet. Evol. 7:476-483. 